\title{
The Role of Cell Autonomous Signaling by BMP in Endocardial Cushion Cells in AV Valvuloseptal Morphogenesis
}

\author{
Yukiko Sugi, Bin Zhou, Kei Inai, Yuji Mishina, and Jessica L. Burnside
}

\author{
Keywords \\ Atrioventricular (AV) canal • Endocardial cushion • BMP-2 • BMP receptors • \\ Valvuloseptal morphogenesis
}

Distal outgrowth and fusion of the mesenchymalized AV endocardial cushions are essential morphogenetic events in AV valvuloseptal morphogenesis. BMP-2 myocardial conditional knockout (cKO) mice die by embryonic day (ED) 10.5 [1] at the initial stage for the formation of endocardial cushions, hampering investigation of the role of BMP-2 in AV valvuloseptal morphogenesis at the later stages. In our previous study, we localized BMP-2 and type I BMP receptors, BMPRIA and Alk2, in AV endocardial cushions [2, 3]. Based on their expression patterns, we hypothesize that autocrine signaling by BMP-2 within mesenchymalized AV cushions plays a critical role during AV valvuloseptal morphogenesis. To test this hypothesis, we employed recently generated endocardial/endocardial cushion-specific cre-driver line $N$ fact $1^{\text {Cre }}$. Unlike a previously generated $\mathrm{Nfatcl}^{\text {enCre }}$ line whose cre-mediated recombination is restricted to $\mathrm{AV}$

\footnotetext{
Y. Sugi $(\bowtie) \cdot$ J.L. Burnside

Department of Regenerative Medicine and Cell Biology, Medical University of South Carolina, 171 Ashley Avenue, Charleston, SC 2925, USA

e-mail: sugiy@musc.edu

B. Zhou

Department of Genetics, Pediatrics, and Medicine (Cardiology), Albert Einstein College of Medicine of Yeshiva University, Bronx, NY, USA

K. Inai

Pediatric Cardiology, Heart Institute, Tokyo Women's Medical University, Tokyo, Japan

Y. Mishina

Department of Biological Materials Science, School of Dentistry, University of Michigan, Ann Arbor, MI, USA
}

T. Nakanishi et al. (eds.), Etiology and Morphogenesis of Congenital Heart Disease,

DOI 10.1007/978-4-431-54628-3_22 

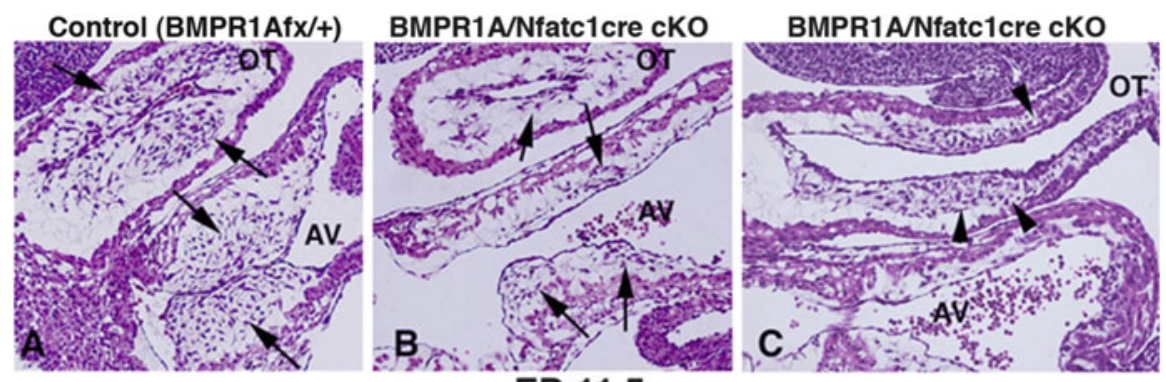

\section{ED 11.5}
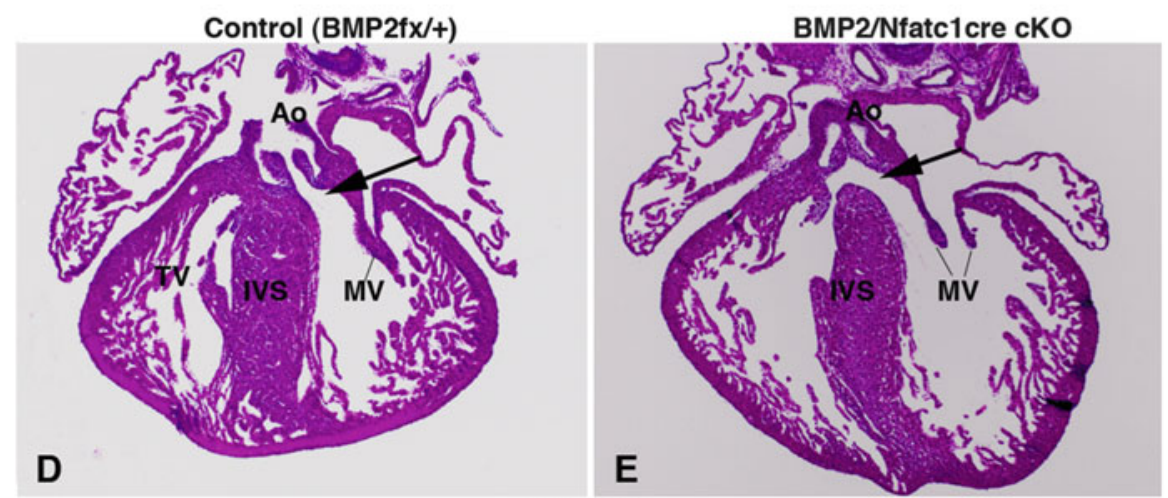

ED 15.5

Fig. 22.1 (a-c) BMPRIA $c K O^{\text {Endo }}$ mouse embryos exhibit failure of cellularization in $\mathrm{AV}$ cushions. Arrows indicate abundant mesenchymal cells in AV and outflow tract (OT) cushions in a control heart (A). Arrows show a few mesenchymal cells in AV and OT in a mutant heart (B). Arrowheads indicate abundant cells at the distal part of the mutant OT, which appear to be neural crest-derived and not reduced by BMPRIA endocardial/cushion-specific inactivation (C). (d, e) Endocardial/cushion-specific deletion of BMP-2 results in perimembranous septal defects (arrow in E), whereas control mouse heart shows well-formed ventricular septum (arrow in D). Ao aorta, $I V S$ interventricular septum, $T V$ tricuspid valves, $M V$ mitral valves

and OT endocardium, this $\mathrm{Nfatcl}^{\mathrm{Cre}}$ line confers cre-mediated recombination within the endocardial cells as well as their mesenchymal progeny. Using the Nfactcl ${ }^{\text {Cre }}$ driver line, we disrupted BMPR1A (Alk3) and BMP-2 specifically from $\mathrm{AV}$ endocardium and endocardial cushions. BMPRIA endocardial cushion cKO $\left(c K O^{\text {Endo }}\right)$ mouse embryos died by ED 12.5 and exhibited failure of cellularization of AV cushions (Fig. 22.1a-c) and disruption of extracellular matrix (ECM) protein deposition in the cushion mesenchyme. On the other hand, AV cushion formation occurred in the $B M P-2 c K O^{E n d o}$ mice that survived beyond the $\mathrm{AV}$ cushion formation stage because BMP-2 expression remained intact in the AV myocardium during $\mathrm{AV}$ cushion formation. $B M P-2 \quad c K O^{E n d o}$ mice exhibited perimembranous ventricular septal defects (VSDs) (Fig. 22.1d, e), defective deposition of ECMs in the membranous septum, and AV mitral valve dysplasia, suggesting the cell autonomous requirement of BMP-2 in AV endocardial cushions. 
$B M P-2 c K O^{E n d o}$ did not exhibit muscular VSDs. These data strongly support our hypothesis that cell autonomous signaling by BMP-2 in the endocardial lineage plays a critical role in mesenchymalized AV cushions during AV valvuloseptal morphogenesis.

Open Access This chapter is distributed under the terms of the Creative Commons AttributionNoncommercial 2.5 License (http://creativecommons.org/licenses/by-nc/2.5/) which permits any noncommercial use, distribution, and reproduction in any medium, provided the original author(s) and source are credited.

The images or other third party material in this chapter are included in the work's Creative Commons license, unless indicated otherwise in the credit line; if such material is not included in the work's Creative Commons license and the respective action is not permitted by statutory regulation, users will need to obtain permission from the license holder to duplicate, adapt or reproduce the material.

\section{References}

1. Ma L, Lu MF, Schwartz RJ, Martin JF. Bmp2 is essential for cardiac cushion epithelialmesenchymal transition and myocardial patterning. Development. 2005;132:5601-11.

2. Sugi Y, Yamamura H, Okagawa H, Markwald RR. Bone morphogenetic protein-2 can mediate myocardial regulation of atrioventricular cushion mesenchymal cell formation in mice. Dev Biol. 2004;269:505-18.

3. Inai K, Norris RA, Hoffman S, Markwald RR, Sugi Y. BMP-2 induces cell migration and periostin expression during atrioventricular valvulogenesis. Dev Biol. 2008;315:383-96. 